《研究ノート》

ニワトリ肧の体外培養システムにおけるアイガモ卵殻の利用

\author{
傍島英雄 ${ }^{1}$ 松原悠子 ${ }^{2} \cdot$ 鏡味 $^{\text {裕 }^{2}}{ }^{*}$ - 田上貴寛 ${ }^{2}$ 春海 隆 ${ }^{2} \cdot$ 内藤 充 $^{2}$ \\ ${ }^{1}$ 岐阜県養鶏試験場，501-3924，岐阜県関市迫間 2672-1 \\ 2 農林水産省畜産試験場，305-0901，茨城県筑波農林研究闷地内局私書箱 5 号
}

\begin{abstract}
ニワトリ胚の体外培養で, 通常ニワトリの二黄卵の卵殼を培養器として用いるシステム则において, アイガモ卵殼の利用を試みた。体外培養システムIにより３日間培養したニワトリ胚をアイガモ卵款と ニワトリ二黄卵の卵殼に移植して培養した結果，アイガモ卵款を用いた場合 18\%（2/11），二ワトリ二黄 卵の卵殼を用いた場合 30\%（3/10）が沺孚化した。孵化した個体については正常な発育, 繁殖能力を示し た。アイガモ卵殸はニワトリ二黄卵の卵殼に比べ，卵殼厚はほぼ同じであったあのの，卵殼膜では約 3 倍の厚さがあり，また気孔は卵殼表面まで筒状でその数は $70 \%$ 程度の分布数であったが，ニワトリ胚の 培養に十分利用できることが示された。
\end{abstract}

（家禽会誌，37 : 175-179, 2000）

キーワード : アイガモ卵，体外培養，ニワトリ二黄卵，二ワトリ胚，稃化

\section{緒訔}

1 細胞期から孵化までのニワトリ受精卵（胚）の体外 培養法はPERRY（1988）によって開発され，その後 NAITO et al. (1990) によって, より卯孚化率の高い方法へ と改良が図られた。この体外培養法では，1 細胞期から 胚盤葉の形成までの 1 日間 (システムI), その後の肧の 形成までの 3 日間 (システムII), さらに胚の成長の過程 から孵化までの 18 日間（システム III）と, 発生段階に応 じて肧を適切な培養容器に移し換えることを特色として いる。この体外培養法の確立により，1細胞期から卯孚化 までのあらゆるステージの胚操作が可能となり, キメラ ニワトリの作出や形質転換二ワトリの作出等の多くの研 究がなされてきている（NAITO, 1997, 1998）。この体外培 養法のシステムIIIにおいてはニワトリの二黄卵の卵款が 主として用いられているが，この他にも七面鳥即款 (RowletT and SimkisS, 1987) やアヒル卵殻（三浦ら, 1991）の利用が試みられ，七面鳥卵殻では $20 \%$, アヒル 卵殻では $9 \%$ の梛化率が報告されている。システム III で は転卵の際に, 鶏胚が殼の開口部を覆うポリェチレン フィルムに接触するのを避けるために, ドナー卵より 10 〜 $15 \mathrm{~g}$ 大きな卯款を用いる。七面鳥やアヒルもその条件

1999 年 11 月 18 日受付 2000 年 1 月 4 日受理

* 現所属 : 麻布大学獣医学部, 229-8501, 神奈川県 相模原市
に適する卵重である。今回の実験では, 最近有機農法へ の利用が盛んに行われ，それにともない産出される卵や 肉の有効な利用が求められるアイガモの期款を用いて, ニワトリ肧の培養を試みた。

\section{材料および方法}

実験に使用したアイガモ卵は，力モメアヒルの雑種固 定種（椎名孵化場，千葉県）の卵である。アイガモ卵扝 よびニワトリ二黄卵は，卵殼の表面を $70 \%$ エルアル コールで消毒し, 鈍端部を直径 $40 \mathrm{~mm}$ に切り取り, 内容 物を出して容器とした。卵殻の準備は二ワトリ胚の移植 当日に行った。培養したニワトリ胚は, 体外培養システ ムIにより 3 日間培養した後, 発育の正常なものを実験 に使用した。ニワトリ胚を移植したアイガモ卵款および ニワトリ卵款の切り口はポリエチレンフィルムで密封 し，転卵しながら $38^{\circ} \mathrm{C}$, 相対湿度 $60 \%$ で 14 日間, さらに 転卵を止めて $37.6^{\circ} \mathrm{C}$, 相対湿度 $70 \%$ で 4 日間培養した。 10 ケ月齢の成雌より採取したアイガモ卵，二ワトリ二黄 卵抢よびニワトリ正常卵それぞれ 20 個ずつについて， 卵重, 長径, 短径, 卵形係数, 卵殻厚, 卵殼膜厚を測定 した。卵殻厚と卵殻膜厚については，ダイアルゲージ (PEACOCK DG-205 尾崎製作所 東京) を用いて各卵 ごとに赤道部付近を 5 力所測定しその平均值を個体の值 とした。また, 卵殻の気孔数は, 卵款膜をはがし乾燥さ せた卵殻に内側からインクを塗布し，外側からしみ出た 
インクを観察する方法により測定した。測定した卵重等 については，アイガモ卵とニワトリ二黄卵を比較する一 元配置による分散分析を行った。
結果

図 1 にアイガモ卵殻およびニワトリ二黄卵の卵殻を用 いて行ったニワトリ胚の培養実験における生存率を示し

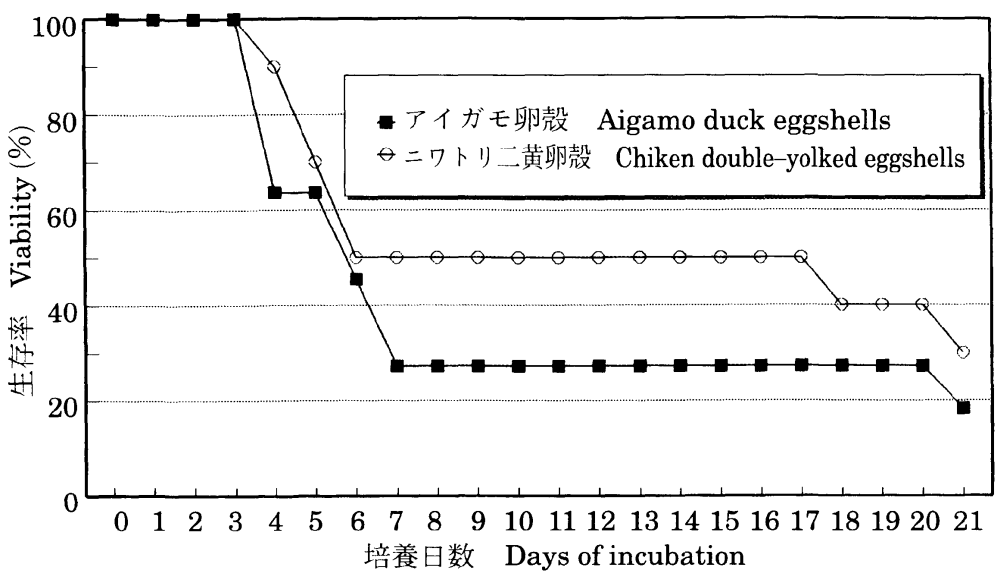

図 1.アイガモ卵殼とニワトリ二黄卵の卵殼を利用した体外培養システム III でのニワトリ胚生存率の推移.

放卵直後，0日目．システム而開始，3日日. 孵化，21 日目.

Fig. 1. Time course of survival rate of chick embryos cultured in Aigamo duck eggshells or chicken double-yolked eggshells. Laid egg, day 0. System III started, day 3. Hatched, day 21.

表 1.アイガモ卵，ニワトリ二黄卵，

Table 1. Egg quality traits of Aigamo duck eggs,

\begin{tabular}{|c|c|c|c|c|}
\hline & $\begin{array}{c}\text { 卵重 }(\mathrm{g}) \\
\text { Egg weight }\end{array}$ & $\begin{array}{c}\text { 長径（mm） } \\
\text { Length }\end{array}$ & $\begin{array}{c}\text { 短径 (mm) } \\
\text { Breadth }\end{array}$ & $\begin{array}{c}\text { 卵形係数 } \\
\text { Egg shape index }\end{array}$ \\
\hline $\begin{array}{l}\text { アイガモ卵 } \\
\text { Aigamo duck eggs }\end{array}$ & $74.4 \pm 3.7^{\mathrm{b}}$ & $63.7 \pm 2.3^{\mathrm{b}}$ & $45.6 \pm 0.7^{\mathrm{a}}$ & $71.7 \pm 2.8^{\mathrm{a}}$ \\
\hline $\begin{array}{l}\text { ニワトリ二黄卵 } \\
\text { Chichen double- } \\
\text { yolked eggs }\end{array}$ & $94.1 \pm 8.1^{\mathrm{a}}$ & $70.3 \pm 4.1^{\mathrm{a}}$ & $49.0 \pm 1.4^{\mathrm{a}}$ & $69.9 \pm 4.2^{\mathrm{a}}$ \\
\hline $\begin{array}{l}\text { ニワトリ正常卵 } \\
\text { Chicken normal } \\
\text { eggs }\end{array}$ & $64.0 \pm 2.7$ & $58.6 \pm 1.8$ & $44.0 \pm 0.9$ & $75.2 \pm 2.8$ \\
\hline
\end{tabular}

平均值士標準偏差, $\mathrm{n}=20$

Mean $\pm \mathrm{SD}, \mathrm{n}=20$.

卵は 10 ヶ月歯の成雌より採卵。

Eggs were obtained from 10 -month old hens.

各測定形質において，アイガモ卵とニワトリ二黄卵の比較で，異符号間に $5 \%$ 水準で有意差あり。

Values in each trait having different superscripts are significantry different $(\mathrm{P}<0.05)$ between Aigamo duck eggs and chicken double-yolked eggs. 
た。いずれの卵壳を用いた場合にも，移植後 3〜4 日の間 に著しく生存率が低下したが，その後孵化までの 10 日 間は生存率の変化は見られず, 归化直前にやや低下し た。孵化率はアイガモ卵殼では $18 \%(2 / 11)$ ，ニワトリ二 黄卵の卵殼では $30 \%(3 / 10)$ であった。捊化した個体は すべて性成熟に達し，正常な繁殖能力を示した。

表 1 はアイガモ卵，ニワトリ二黄卵およびニワトリ正 常卵を比較したものである。アイガモ卵は卵重では二ワ トリ二黄卵より $20 \mathrm{~g}$ 程度小さかったものの, 卵形係数 はやや大きかった。また，卵殸厚には両者に大きな差は 認められなかったが，卵殻膜厚についてはアイガモ卵の 方がニワトリ卵に比べ約 3 倍の厚さを示した。卵款の気 孔の分布については，卵によるばらつきが大きかったも のの，いずれの卵においても鋭端部から鈍端部にかけて 増加する傾向が認められた。アイガモ卵はニワトリ卵に 比べ全体的に気孔数が少なく，赤道部の平均値で約 70\% の值を示した。また図 2 に示すように，ニワトリ卵の気 孔の形状は表面に向け漏斗状に広がっているのに対し， アイガモ卵では内側から表面近くまで，その形状に大き な变化は認められなかった。

\section{考察}

ニワトリ胚の体外培養は，古くはポリエチレンフィル ム等を用いて行われ，主に初期胚の発生の観察に用いら れてきた（DUNN, 1974 ; DUNn and BOONE, 1977 ; 後藤
ら，1988）。この力法では, 胚の初期発生は正常に行われ るものの，それ以降発生の進行がしだいに遅れ，孵化す ることはなかった。ニワトリ胚が培養下に打いて正常に 発生するためには，胚における酸素の取り込み亡炭酸力゙ スの放出，すなわち呼吸作用之，胚が利用するカルシウ ムの供給が正常に行われる必要がある。二ワトリ肧で は，孵卵の 19〜20日目頃までは漿尿膜が卵殼膜と接触 し，気孔を通じて呼吸作用を行うとともに，肧が利用す るカルシウムの約 $80 \%$ を卵殻から吸収することになる (FREEMAN and VINCE, 1974)。二ワトリや七面鳥，アヒ ル，アイガモ等の卵殼を用いた場合，程度の差はあって 屯，これら呼吸作用やカルシウムの供給が行われたた め, ニワトリ胚を孵化させることができたものと考えら れる。

最近，ウズラ肧を空気透過性のテフロン膜を用いて培 養し，梛化させることに成功しており（KAMIHIRA et al. 1998)，鳥類胚の培養に必ずしも卵款を用いる必要がな くなってきた。このような完全なインビトロにおける培 養系を用いることにより，二ワトリ胚の発生過程におけ る卵壳の役割を，より詳しく解析できる可能性がでてき た。

本実験により，アイガモ卵殼を用いて二ワトリ肧を餒 化させることは十分可能であることが証明された。アイ ガモ卵殻はニワトリの卵殻に比べ卵殻の厚さはほぼ同じ であるのに対して，卵款膜が約 3 倍の厚さをもつとと屯

\section{ニワトリ正常卵における卵形質の比較}

chichen double-yolked eggs and chicken normal eggs

\begin{tabular}{|c|c|c|c|c|}
\hline \multirow{2}{*}{$\begin{array}{l}\text { 卵款厚 }(\mu \mathrm{m}) \\
\text { Egg shell } \\
\text { thickness }\end{array}$} & \multirow{2}{*}{$\begin{array}{c}\text { 卵凯膜厚 }(\mu \mathrm{m}) \\
\text { Thickness of } \\
\text { eggshell } \\
\text { membranes }\end{array}$} & \multicolumn{3}{|c|}{$\begin{array}{c}\text { 気孔数 }\left(/ \mathrm{cm}^{2}\right) \\
\text { Number of pores }\end{array}$} \\
\hline & & $\begin{array}{l}\text { 赤道部 } \\
\text { Equatorial } \\
\text { region }\end{array}$ & $\begin{array}{l}\text { 鈍端部 } \\
\text { Blunt } \\
\text { end }\end{array}$ & $\begin{array}{l}\text { 鋭端部 } \\
\text { Pointed } \\
\text { end }\end{array}$ \\
\hline $341 \pm 26^{\mathrm{a}}$ & $46 \pm 7^{\mathrm{a}}$ & $79 \pm 18^{\mathrm{a}}$ & $93 \pm 21^{\mathrm{a}}$ & $68 \pm 32^{\mathrm{a}}$ \\
\hline $350 \pm 25^{\mathrm{a}}$ & $15 \pm 4^{\mathrm{b}}$ & $113 \pm 20^{\mathrm{a}}$ & $114 \pm 29^{\mathrm{a}}$ & $76 \pm 41^{\mathrm{a}}$ \\
\hline $363 \pm 23$ & $14 \pm 4$ & $109 \pm 21$ & $131 \pm 31$ & $85 \pm 43$ \\
\hline
\end{tabular}



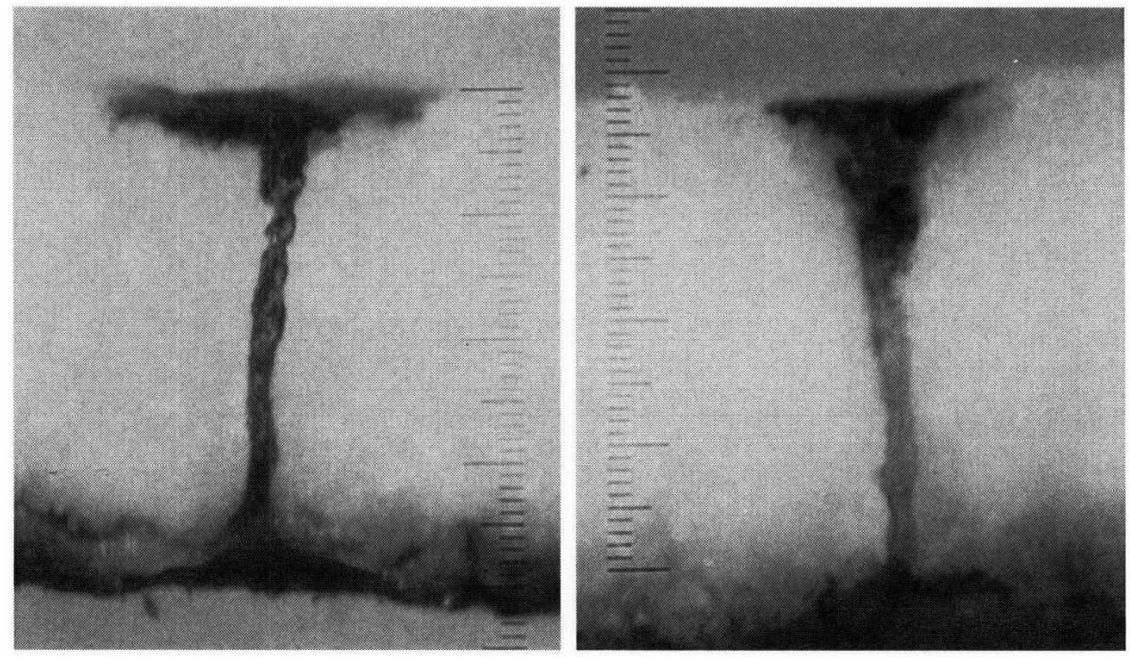

図 2. アイガモ卵(左)とニワトリ二黄卵（右）の気孔の形状.

どちらも上側が卵款表面.

*図中の最小目盛のスケールは 9 マイクロメーター.

Fig. 2. Pore shape of Aigamo duck eggshell (left) and chicken doubleyolked eggshell (right).

Egg surface lies upper side in both figures.

${ }^{*}$ Minimum scale $=9 \mu \mathrm{m}$.

に気孔の形状が異なり，さらにその分布が少ないことが 特徵となっている。これらの卵殻の特徵は, アイガモが 水禽類であり水辺の湿ったところに巣を作るため, 泥や 雑菌などの污染から卵内容物（胚）を保護するのに適し ていると考えられる。これらのことがニワトリ二黄卵の 卵款を利用した場合しくこべて，卯孚化率の差に影響して いるのかどうか, 今後例数を増やしてさらに検討するこ とが必要である。

\section{謝辞}

アイガモ飼養等でご協力いただいた岐阜県養鵎試験場 の同僚諸氏に感謝申し上げます。

\section{引 用 文 献}

DunN, B.E. (1974) Technique for shell-less culture of the 72-hour avian embryo. Poultry Science, 53 : 409-412.

Dunn, B.E. and Boone M.A. (1977) Growth and mineral content of cultured chick embryos. Poultry Science, $56:$ 662-672.

Freeman, B.M. and Vince M.A. (1974) Development of the Avian Embryo, pp. 237-248. Chapman and Hall, London.

後藤和文・高橋陽子・中西喜彦・小川清彦（1988）鶏受
精卵の卵款外発生. 日本家离学会誌, $25: 27-33$.

KaminiRa, M., Oguchi S., Tachibana A., Kitagawa Y., and IIJIMA S. (1998) Improved hatching for in vitro quail embryo culture using surrogate eggshell and artificial vessel. Development Growth and Differentiation, $40:$ 449-455.

二浦克洋・末吉益雄・神部昌行 ・ 岡 基 (1991) ア上 ル卵殼を用いた鶏胚の培養一最初の卯孚化例一，実験動 物学会誌, $40: 251-254$.

NAITO, M. (1997) The microinjection of DNA into early chicken embryo. In 'Transgenic Animals : Generation and Use (Houdebine, L.M. ed.)', pp. 6973. Harwood Academic Publishers, Netherlands.

NAITO, M. (1998) Manipulation of primordial germ cells for avian transgenesis. AgBiotech News and Information, 10 : 397-404.

Naito, M., Nirasawa K., and Oishi T. (1990) Development in culture of the chick embryo from fertilized ovum to hatching. Journal of Experimental Zoology, 254 : 322-326.

PERry, M.M. (1988) A complete culture system for the chick embryo. Nature, 331 : 70-72.

Rowlftт, K. and Simkiss K. (1987) Explanted embryo culture : in vitro and in ovo techniques for domestic fowl. British Poultry Science, 28 : 91-101. 


\title{
Culture of Chicken Embryos Using Aigamo Duck Eggshells
}

\author{
Hideo Sobajima', Yuko Matsubara ${ }^{2}$, Hiroshi Kagami ${ }^{2 *}$, Takahiro Tagami², \\ Takashi HARUmi ${ }^{2}$ and Mitsuru NAITO ${ }^{2}$ \\ ${ }^{1}$ Gifu Prefectural Poultry Experimental Station, Seki, Gifu 501-3924 \\ ${ }^{2}$ National Institute of Animal Industry, Tsukuba Norindanchi P.O. Box 5, Ibaraki 305-0901
}

Chicken embryos incubated for 3 days were cultured using Aigamo duck eggshells or chicken double-yolked eggshells. The hatching rates were $18 \%(2 / 11)$ for Aigamo duck eggshells and 30\% (3/10) for chicken double-yolked eggshells. The hatched chicks reached sexual maturity and showed normal reproductive performance. The thickness of the Aigamo duck eggshell was almost the same as that of the chicken eggshell, but the eggshell membranes were about three times thicker. The number of pores per $\mathrm{cm}^{2}$ eggshell was about $30 \%$ less in the Aigamo duck eggshell compared with those in the chicken double-yolked eggshell. The results show that Aigamo duck eggshells could be used for culturing chicken embryos as a surrogate eggshell.

(Jpn. Poult. Sci., 37 : 175-179, 2000)

Key words : Aigamo duck egg, embryo culture, chicken double-yolked egg, chick embryo, hatch

*Present address : School of Veterinary Medicine, Azabu University, Sagamihara, Kanagawa 229-8501 